\title{
OPTIMALISASI PRODUK BATIK PERAJIN BATIK PLENGKUNG DUSUN DALANGAN DESA CAMPURSARI KABUPATEN TEMANGGUNG JAWA TENGAH
}

\author{
Sri Wuryani, FP \\ Jurusan Kriya \\ Fakultas Seni Rupa dan Desain ISI Surakarta \\ Email: sriwuryani718@yahoo.co.id
}

\begin{abstract}
Abstrak
Desa Campursari salah satu desa di Kecamatan Bulu, Temanggung Kabupaten Temanggung, Provinsi Jawa Tengah. Secara geografis, Desa Campursari terletak di kaki gunung Sumbing pada ketinggian $1.040 \mathrm{~m}$ dpl, berjarak $1 \mathrm{~km}$ dari ibukota Kecamatan Bulu dan 9 km dari Ibukota Kabupaten. Desa Campursari terbagi atas lahan sawah dan bukan sawah.Lahan sawah dipergunakan ladang/tegalan/huma, perkebunan rakyat dan lain-lain.Letak desa sedemikian memberikan sumber daya alam yang berlimpah.Hasil perkebunan merupakan penunjang ekonomi warga, diantaranya perkebunan tembakau yang menjadi primadona.Kesibukan warga pada masa panen tembakau, antara bulan Juli, Agustus dan September.Diluar bulan-bulan tersebut banyak waktu luang, terutama bagi ibu-ibu. Mengisi waktu luang inilah mereka ingin mengisi dengan menambah pengetahuan tentang batik yang selama ini sudah dirintis di dusun Dalangan Desa Campursari, Kegiatan tersebut diwadahi dalam kelompok yang diberi nama Batik Plengkung. Permasalahan kelompok batik plengkung kualitas kain batik yang kurang baik warna tidak rata dan proses pewarnaan yang kurang praktis. Tujuan pelatihan menambah ketrampilan dan wawasan tentang batik, memberikan motivasi untuk lebih mencintai batik kepada warga desa Campursari, terutama peserta pelatihan. Hasil pelatihan diharapkan dapat meningkatkan jumlah produksi dan kualitasnya, memunculkan perajin-peraji baru sebagai pencipta lapangan pekerjaan, dan kesejahteraan warga meningkat. Metode yang digunakan dalam kegiatan ini adalah pelatihan dan pendampingan tentang teknik mewarna dengan bahan warna sintetis. Hasil pelatihan, peserta akanbertambah pengetahuannya tentang jenis bahan pewarna sintetis dan teknik penggunaannya, karya hasil pelatihan,
\end{abstract}

Kata kunci: pelatihan, batik plengkung, warna sintetis.

\begin{abstract}
Campursari is one of the villages in Bulu District, Temanggung, Central Java Province. Geographically, Campursari Village is located at the foot of Mountain Sumbing at an altitude of 1,040 $\mathrm{m}$ above sea level, located $1 \mathrm{~km}$ from the capital of Bulu District and $9 \mathrm{~km}$ from the Capital District. Campursari village is composed into paddy fields and not paddy fields. Paddy fields are used as fields / dry fields / huma, community plantations and others. The location of such villages provides abundant natural resources. The results of plantations are economic support for residents, including tobacco plantations that are excellent. Residents are busy at the time of the tobacco harvest, between July, August and September. Outside these months there is plenty of free time, especially for mothers. This free time they want to fill by adding knowledge about batik that had been pioneered in the Dalangan hamlet in Campursari village, the activity was accommodated in a group named Batik Plengkung. The problem with the Plengkung batik group is that the quality of
\end{abstract}


batik cloth is not good, the colors are uneven and the coloring process is not practical. The aim of the training is to add skills and insights about batik, to provide motivation to love batik more to Campursari villagers, especially the trainees. The results of the training are expected to increase the amount of production and quality, bring new craftsmen as job creators, and improve the welfare of citizens. The method used in this activity is training and mentoring on coloring techniques with synthetic color materials. The results of the training, participants will increase their knowledge about the types of synthetic dyes and their use techniques, the results of the training.

Keywords: training, batik Plengkung, synthetic colors.

\section{PENDAHULUAN}

Campursari salah satu nama desa di lereng Gunung Sumbing, di Kecamatan Bulu, Kabupaten Temanggung. Campursari selain memiliki potensi sumber daya alam, juga memiliki potensi kesenian tradisional dan kerajinan traidisional terutama batik. baku dan mengandung makna simbolis terkait dengan agama dan kepercayaan setempat. Pendampingan dilakukan terbatas pada waktu latihan persiapan pentas peringatan HUT Kemerdekaan RI, yang dilaksanakan tanggal 18 Agustus 2018. Pertimbangan kondisi tersebut, pelatihan di fokuskan pada kerajinan batik untuk memperkuat UKM di desa Campursari. Pertimbangan lain adalah kesesuaian dengan bidang kopetensi penulis sebagai pelaksana PPM yaitu tekstil, termasuk batik.

Desa Campursari, mulai merintis kerajinan batik sekitar tiga tahun yang lalu, dengan mengadakan pelatihan batik. Pelatihan berlanjut, dikembangkan oleh ibu-ibu kelompok penggiat batik di dusun Dalangan dan diberi nama "Batik Plengkung". Nama diambil dari nama ikon desa Campursari yaitu Plengkung. Plengkung yang dimaksud adalah semacam bentuk jembatan, tetapi sebenarnya adalah saluran air yang di bamgun pada masa Belanda. Meskipun bentuknya lurus, tetapi warga sekitar menyebutnya Plengkung akhirnya dikenal dengan Plengkung (Ibu Marsono, wawancara 28 Juli 2018; Ibu Ambar, wawancara 25 Agustus 2018). Kain batik yang dibuat terutama batik tulis dengan pewarnaan alam. Proses pembuatan kain batik, yang memerlukan waktu lama dan ketekunan. Batik Plengkung di satu sisi sudah mulai dikenal dan banyak permintaan untuk melatih di sekolah-sekolah, sebagai usaha sekolahan untuk membekali ketrampilan bagi anak didiknya.

Berdasarkan analisis situasi yang ada di Batik Plengkung, adalah terbatasnya pengetahuan tentang batik, terutama proses mbabar yang lebih cepat dan kualitas produk kain batik yang dihasilkan. Batik salah satu budaya leluhur bersifat adiluhung yang perlu di lestarikan. Kain Batik mengandung makna simbol terkait dengan kepercayaan dan budaya Jawa, baik dari nama, warna dan motif (Femina,1985). Pengakuan UNESCO terhadap Batik tradisional Indonesia sebagai budaya Dunia dan ditetapkan tanggal 2 Oktober sebagai hari batik. Pengakuan tersebut memberi angin segar bagi perkembangan batik. Batik sebelumnya mengalami pasang surut tidak menentu, dan hanya dikenal di beberapa kota antara lain Surakarta, Yogyakarta, Pekalongan dan kota-kota batik lainnya, kini hampir setiap daerah mempunyai usaha batik dengan corak khas masing-masing daerah. Batik Plengkung, yang dimotori oleh Ambar yang merintis kerajinan batik di desa Campursari, memerlukan pelatihan dan pendampingan untuk pengembangannya, termasuk dalam menciptakan corak khas desa Campursari. Ketrampilan yang terbatas namun semangat ibu-ibu kelompok penggiat batik, memberi harapan tercapainya tujuan menjadikan kerajinan batik sebagai salah satu penopang ekonomi keluarga, sekaligus melestarikan budaya lokal dapat tercapai.

Permasalahan yang dihadapi kelompok Batik Plengkung dari hasil observasi, pertama minimnya SDM dalam membuat desain batik, 


\section{Abdi Seni Jurnal Pengabdian Kepada Masyarakat}

sehingga desain masih sangat minim dan kurang bervariasi. Disatu sisi banyak alternatif teknik untuk membuat desain batik lebih bervariasidan menarik.

Kedua mereka baru mengenal warna alam, kain batik yang dihasilkan terbatas dan harga jual tinggi. Padahal bahan warna sintetis sebagai alernatif, lebih praktis dan murah dengan berbagaijenis sesuai dengan kebutuhan untuk colet atau untuk celup, Proses yang cepat dengan bahan warna yang murah, harga jual akan terjagkau.

Permasalahan ketiga minimnya peralatan, pengetahuan teknik dan proses mewarna yang terbatas maka hasilnya, warna kain batik tidak rata atau belang-belang. Dengan teknik yang benar, telaten dan didukung peralatan yang standart dapat menghasilkan kain batik yang berkualitas.

Permasalahan ke empat kesadaran wirausaha, pekerjaan warga mayoritas bercocok tanam atau bekerja di perkebunan tembakau. Mereka merasa lebih nyaman dan cukup dengan pekerjaannya, dari pada berwirausaha yang dipandang lebih sulit dan kompleks permasalahannya,

Berdasarkan fenomena-fenomena permasalahan tersebut, penulis bermaksud mengadakan pelatihan batik, khususnya teknik mewarna dan penggunaan bahan warna sintetis. Sasaran pelatihan untuk warga desa Campursari Kecamatan Bulu Kabupaten Temanggung khususnya anggota Batik Plengkung, guna memperkaya keterampilan, menambah wawasan tentang batik, meningkatkan kreativitas dan meningkatkan produksi batik. Memberikan motivasi sehingga diharapkan muncul perajin-perajin batik baru dan memperluas lapangan pekerjaan, imbasnya meningkatnya kesejahteraan warga.

\section{PEMBAHASAN}

Berdasarkan permasalahan-permasalahan yang ada, dari hasil diskusi dengan anggota dan koordinator Batik Plengkung, perlu mencari solusi untuk membantu mitra dalam mengatasi permasalahannya. Langkah selanjutnya penulis mencoba mencari solusi dengan metode pelaksanaan pengabdian pada masyarakat melaluitahapan: mitra mengajukan permohonan lewat LP3MP ISI Surakarta, penulis mengadakan observasi, kesepakatan dengan mitra tentang materi yang akan menjadi bahan pelatihan, pembuatan proposal PPM untuk memperoleh dana pelaksanaan (PPM), proposal di setujui dan memperoleh dana, pelaksanaan PPM, pendampingan, evaluasi dan membuat laporan.

Hasil obervasi dan wawancara dengan koordinator batik plengkung, secara garis besar permasalahan adalah dari sisi desain, peralatan, dari teknik mewarna dan meningkatkan jumlah produksi. Pengetahuan tentang desain sangat minim, sehingga desain batik yang dihasilkan sangat minim, kurang bervariasi dan kurang menarik. Peralatan yang dimiliki belum standar, terutama alat untuk mewarna masih menggunakan ember kecil. Proses pewarnaan menjadi tidak maksimal, kain tidak dapat menyerap zat warna dengan sempurna, hasilnya warna kain tidak rata. Terlebih bahan warna yang digunakan bahan warna dari alam, yang memerlukan waktu lama proses penyerapannya. Teknik mewarna yang tidak benar sangat berdampak pada hasil akhir kain batik yang dihasilkan. Meskipun dengan peralatan yang minim bila diimbangi dengan teknik mewarna yang benar, akan meminimalisir kekurangan kain batik yang dihasilkan. Berdasarkan pertimbanganpertimbangan tersebut diambil kesepakatan dengan mitra, penulis dalam kegiatan PPM memberikan pelatihan dan pendampingan dalammembuat desain dan teknik mewarna dengan bahan warna sintetis jenis naptol. Kegiatan pelatihan batik yang diadakan ini, setelah selesai diharapkan dapat lebih memotivasi warga terutama generasi muda, muncul sebagai perajin-perajin batik yang baru dengan inovasiinovasinya. Lapangan pekerjaan dengan demikian lebih luas sekaligus melestarikan batik sebagai budaya lokal. 


\section{PELAKSANAAN PROGRAM}

Waktu pelaksanaan pelatihan batikdisepakati dalam 2 hari tgl 24 dan 25 bulan Agustus 2018, pukul 13.00-selesai,dipilih waktu istirahat ibu-ibu, setelah bekerja di kebun atau tempat lainmya, demikian pula siswa setelah pulang sekolah dapat mengikuti pelatihan. Tempat pelatihan diposko Batik Plengkung di dusun Dalangan.

\section{Materi pelatihan}

Materi Pelatihan yaitu lebih pada teknik pewarnaan yang benar dan jenis bahan warna dipakai yaitu naptol garamgaram. Materi teori diberikan untuk mengantarkan praktek membuat desain dan membuat kain batik. Proses pelekatan lilin digunakan dua macam sesuai keinginan peserta, yaitu dengan canting tulis atau canting cap yang baru dimiliki kelompok Batik Plengkung. Pendampingan dilakukan selama pelatihan dari membuat desain, proses pelekatan lilin, proses mbabar sampai selesai. Pasca pelatihan batik pada kegiatan PPM, penulis tetap berkomunikasi dengan mitra untuk menjalin keja sama bila ada permasalahan dapat berdiskusi.

\section{Membuat Desain.}

Pelatihan diawali dengan membuat desain, rancangan hiasan yang akan dibatik untuk menghias kain. Menghias tidak lepas dengan istilah motif, pola, pengulangan dan sanggit. Unsur hiasan/ornamen yang utama adalah motif. Motif menurut Gustami, bagian atau unsur terkecil dari ornament atau hiasan. Motiflah yang menjadi pangkal atau pokok dari suatu pola, motif setelah mengalami pengulangan dan ditebarkan secara berulang-ulang akan memperoleh pola. (Gustami, 1980:6) Motif dapat berbentuk apapun dari yang terkecil seperti titik (cecek) sampai obyek yang besar. Obyek atau sumber ide membuat motif, dari apa yang ada di lingkungan sekitar: tumbuhan, hewan, batu-batuan ataupun properti pertunjukan seperti tari topeng ireng, tari kuda lumping dan sebagainya diolah dengan di stilasi sesuai kebutuhan untuk motif batik yang menjadi motif khas desa Campursari.

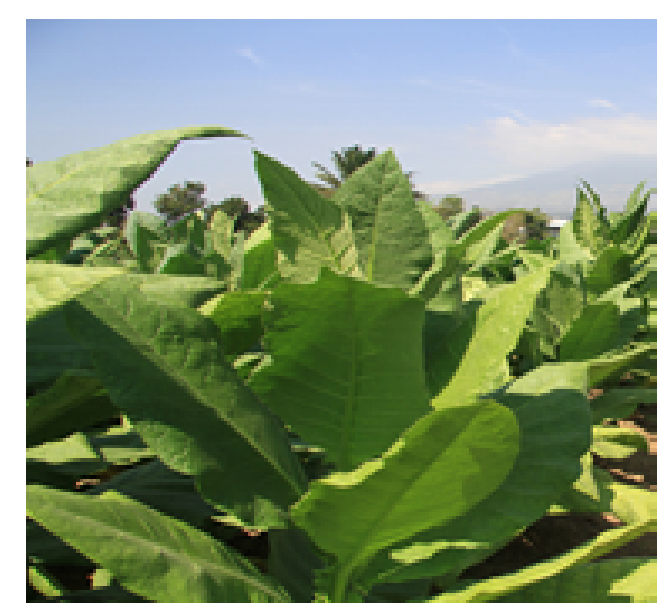

Tanaman Tembakau Foto: Wisnu Adi Permana

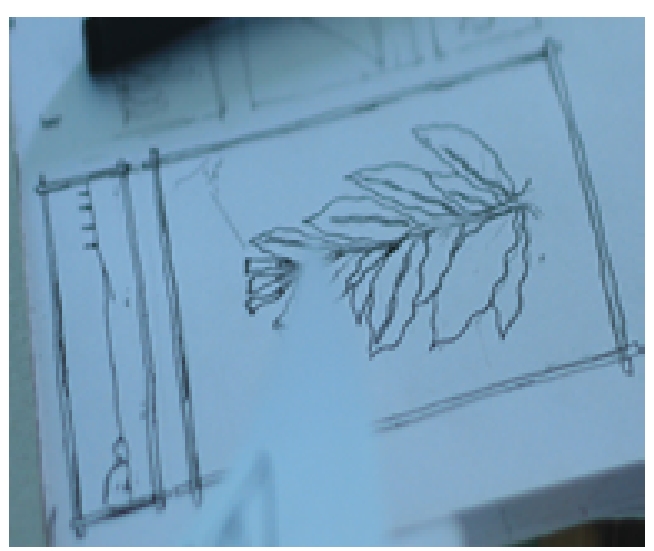

Motif dengan ide dari tanaman tembakau Foto: Wisnu Adi Permana

\subsection{Struktur Pola Batik}

Struktur atau susunan dimaksudkan, cara bagaimana unsur-unsur dasar dari masing-masing kesenian telah tersusunhingga berwujud. Penyusunan meliputi pengaturan yang khas, sehingga terjalin hubungan yang berarti diantara bagian-bagian dari keseluruhan perwujudan itu, sehingga merupakan ornament tertentu. (Djelantik, 1999: 21).Penerapannya dalam batik, Struktur pola batik terdiri dari motif-motif batik yang disusun/ dikoordinasikan berdasarkan aturan yang ada. Susunan pola batik menurut Sewan Susanto, terdiri dari: 
1) motif utama,merupakan unsur pokok dari pola, berupa gambar-gambar bentuk tertentu merupakan suatu corak dari batik sebagai pengisi bidang utama.Pada umumnya ornament utama mempunyai arti dan mengandung kejiwaan dari batik.

2) motifpendukung/pengisi latar), merupakan pola berupa gambar-gambar sebagai ornament tambahan untuk mengisi bagian bidang kosong diantara motif utama. Bentuknya lebih kecil dari motifutama.

3) motif isen-isen, isian berfungsi memperindah pola secara keseluruhan, diterapkan pada motif pokok maupun motif pengisi. Motif isen lebih kecil dari motif pokok maupun motifpengisi mis; cecek, sawut, sirapan, cacah gori, dll (Sewan Susanto,1980: 261; Dharsono, 2015: 49-50)

Motif-motif disusun dalam satu unit, sebelum nanti diulang-ulang untuk menghias suatu benda.Teknik menyusun dapat menggunakan salah satu dari bermacam-macam teknik yang dikenal yaitu; berhadapan, bertolak belakang, berputar dan berseberangan. Teknik penyusunan yang beredabeda untuk memperoleh kesan yang bervariasi, dinamis tidak monoton, sehingga menarik bagi konsumen.

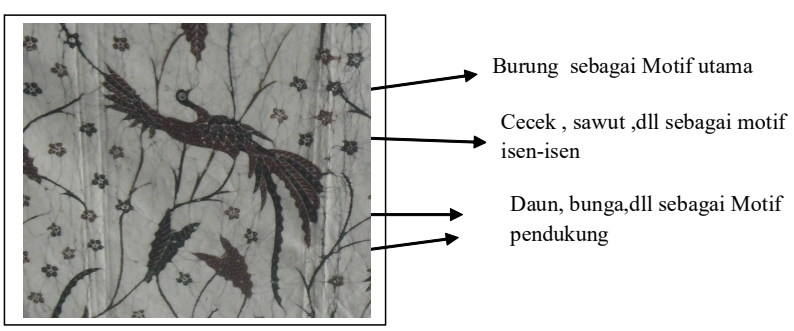

Kain batik kebumen. Foto: FP Sri Wuryani

\subsection{Menyusun Motif}

Motif-motifkemudian disusun menjadi satu Unit. Menurut Z. Groscki,1980:249-292 ada bermacam-macam teknik yaitu: berhadapan, teknik menyusun motif, dua atau lebih motif yang saling berhadapan, muka/ bagian depan obyek yang satu menghadap bagian depan obyek lainnya.

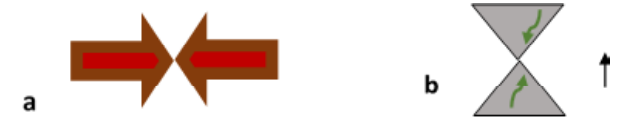

a) Bertolak belakang, Teknik menyusun motif, dua atau lebih motif yang saling membelakangi.bagian belakang obyek yang satu menghadap bagian belakang obyek lainnya
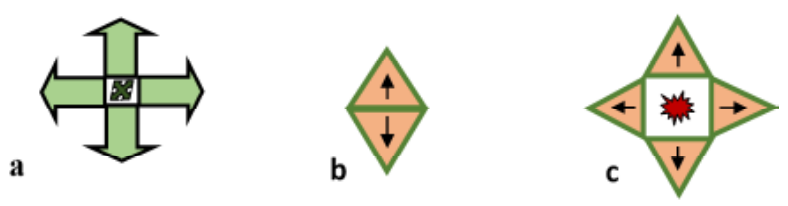

b) Berputar. Teknik menyusun motif, dua atau lebih motif bagian atas obyek yang satu, terletak di samping bagian atas obyek lainnya, sehingga mendapatkan kesan berputar,
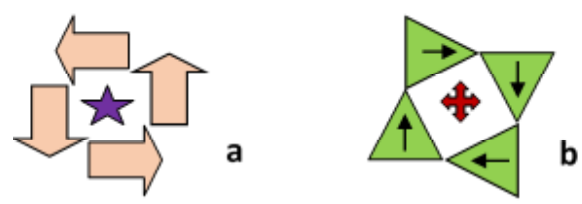

c) Berseberangan.
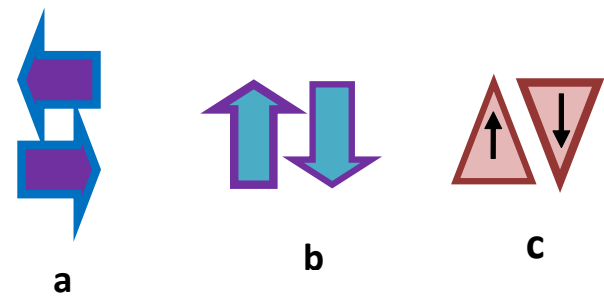

\subsection{Pola ulang (Repeat)}

Susunan motif(Unit) kemudian di ulangulang sehingga menutup permukaan kain. Teknik pengulangan mmenurut Z. Groscki,1980:249-292 dikenal bemacam-macam yaitu:

a) ejajar, unit/pola disusun dengan mengulangulang kekiri dan kekanan menurut arah horizontal ke depan dan ke belakang. 

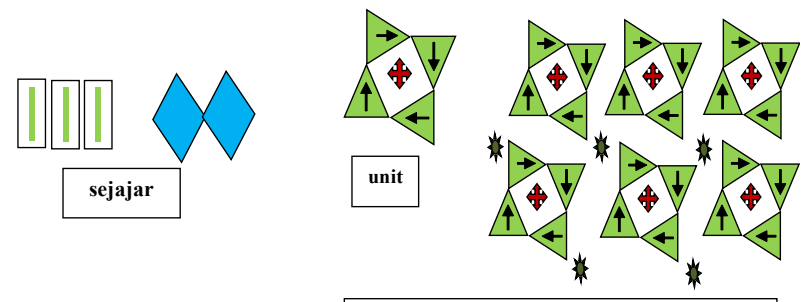

Unit di ulang dengan teknik pengulangan sejajar

b.). Pengulangan sejajar turun satu langkah
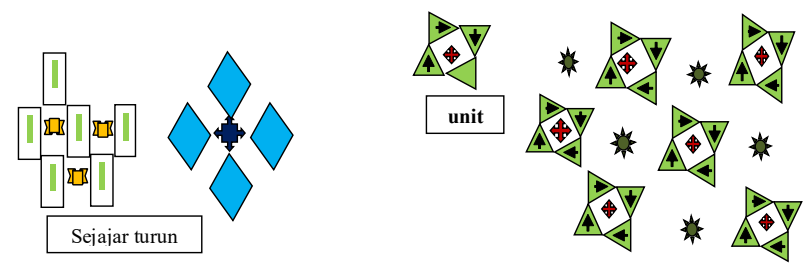

a) andha endhe atau setengah langkah. Unit/ pola disusun dengan mengulang-ulang kekiri dan kekanan, ke atas bawah menurut arah horizontal dengan menurunkan setengah pola/unit.
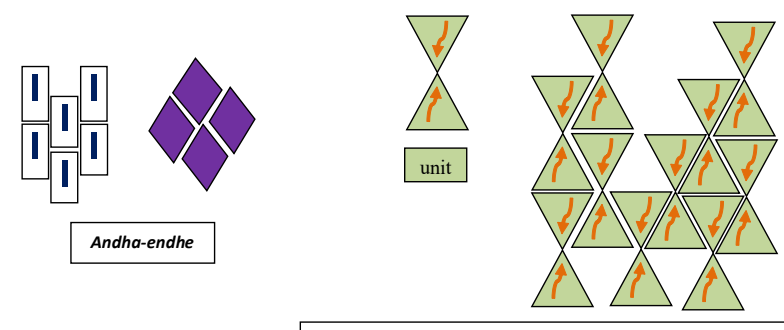

Unit di ulang-ulang dengan teknik pengulangan ondho

b) diagonal, unit/pola disusun dengan mengulang-ulang kekiri dan kekanan menurut arah garis diagonal atau miring
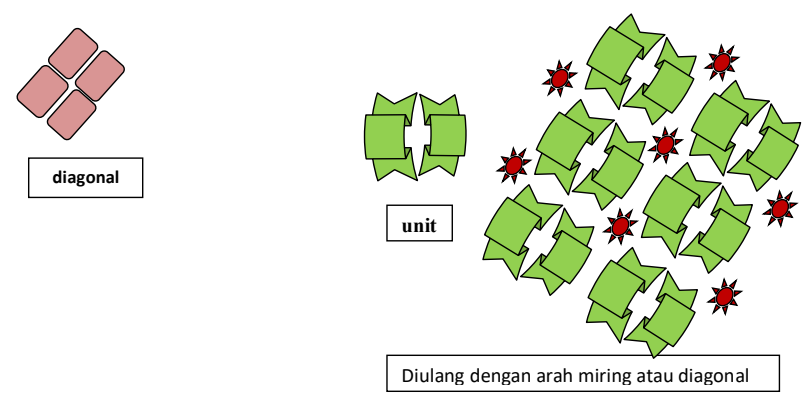

\section{Proses Membuat Kain Batik.}

\subsection{Persiapan Alat dan Bahan.}

Peralatan dan Bahanyang diperlukan dan dipersiapkan dalam pelatihan batik adalah canting, wajan, kompor, gawangan, untuk mewarna bak celup/ember, sarung tangan, dan sebagainya. Bahan diperlukan kain mori putih, lilin batik sebagai perintang lilin, bahan warna dan lainnya,

\subsection{Bahan Warna.}

Warna batik dikenal dari warna alam dan warna sintetis.perajin di desa Campursari sudah mengenal ahan warna alam, untuk bahan warna sintetis masih kurang. dalam pelatihan dipilih jenis naptol garam. Bahan warna sintetis ini seringkali digunakanuntuk mewarna kain batik, warna yang dihasilkan mendekati warna batik dari bahan alam..Mewarna dengan Naphtol Garam, terdiri dari dua bagian yaitu naptol dan garam. Naptol dalam pemasaran menggunakan simbol AS diikuti kode arah warna: ASG (kuning), ASLB (coklat), ASBO (hitam), ASD (merah jambu) dan sebagainya. Sedangkan untuk Garam menunjuk langsung pada kode warna misalnya Biru B, Biru BB, Merah R, Merah B, Kuning GC, Violet, Hitam $\mathrm{B}$, dan seterusnya Mewarna dengan naphtol diperlukan dua larutan, tahap I kain yang sudah dibatik dimasukan kedalam larutan naphtol, pada tahap ini kain akan berwarna kuning, tetapi kalau kena air akan luntur. Selanjutnya dicelup kedalam larutan Garam, pada tahap ini warna baru akan muncul. Perbandingan untuk mewarna antara naphtol dan garam adalah $1: 2-3$. Kebutuhan bahan warna untuk $1 \mathrm{~m}$ kain diperlukan naptol/garam 3-5 gram per liter air. Kain batik untuk nyamping berukuran 2,25 m-2,5 m,

Batik tradisional Surakarta dan Yogyakarta hanya dua macam warna yaitu warna biru dan warna coklat. Mbabar atau proses dalam batik tradisi, pewarnaan tahap pertama adalah mewarna biru, dalam batik pekerjaan mewarna biru disebut medel. Kemudian untuk warna ke dua yaitu warna coklat disebut soga, pekerjaan mewarna coklat disebut 
nyoga. Warna tradisi tersebut dalam bahan warna sintetis untuk mewarna biru diperlukan bahan

\section{Larutan I: Naptol:}

\section{4 gramAS /liter}

8 gram soda kostik, 4-8 gram TRO,

air panas secukupnya, untuk melarutkan

\section{Larutan II: Garam Diazo}

\section{8 -12 gram/literBiru BB} atau Biru B atau campuran keduanya. air dingin dituang sedikit sedikit sambil diaduk sampai homogen

\section{Cara melarutkan bahan warna:}

Larutan I, Larutan Naptol,

a) 9-15 gram bubuk naphtol ( AS ) dibuat pasta dengan menuangkan TRO, diaduk sampai rata

b) Selanjutnya dituangkan air panas sedikit demi sedikit kira-kira 15-25 cc sambil diaduk hingga tercapur/homogen

c) Soda kostik dimasukan sedikit demi sedikit sambil diaduk, hingga diperoleh larutan yang jernih kekuningan. Apabila soda kostik sudah habis tetapi larutan masih keruh larutan dapat dipanaskan diatas api kecil dengan hati- hati sambil diaduk-aduk sampai jernih.

Larutan II: Laturan garam .

a) (18-27) - (30/45) gram garam diazo, (Biru B atau Biru BB) dibuat pasta terlebih dahulu dengan cara dituang air dingin sedikit demi sedikit diaduk sampai rata

b) kemudian ditambah air secukupnya

\section{Proses Batik Tulis meliputi :}

1) Mola atau nyorek, adalah memindah desain (gambar dikertas) ke permukaan kain purih, menggunakan pensil.
1) Nglowongi/Membatik Klowong, menorehkan lilin dengan menggunakan alat canting, pada bagian tepi motif-motif yang telah digambar di kain.

2) Ngiseni, membatik di bagian dalam motif utama dan motif pendukung dengan motif isen-isen seperti cecek.sawut, sirapan, ukel, dll berfungsi memperindah penampilan motif

3) Nerusi, selesai dibatik selanjutnya diterusi, dengan cara membatik ulang bagian belakang/ sebaliknya sesuai pola kain yang sudah dibatik $($ no, 4$)$

4) Nembok, menutup bagian batikan yang dikehendaki tetap putih tidak terkena warna.

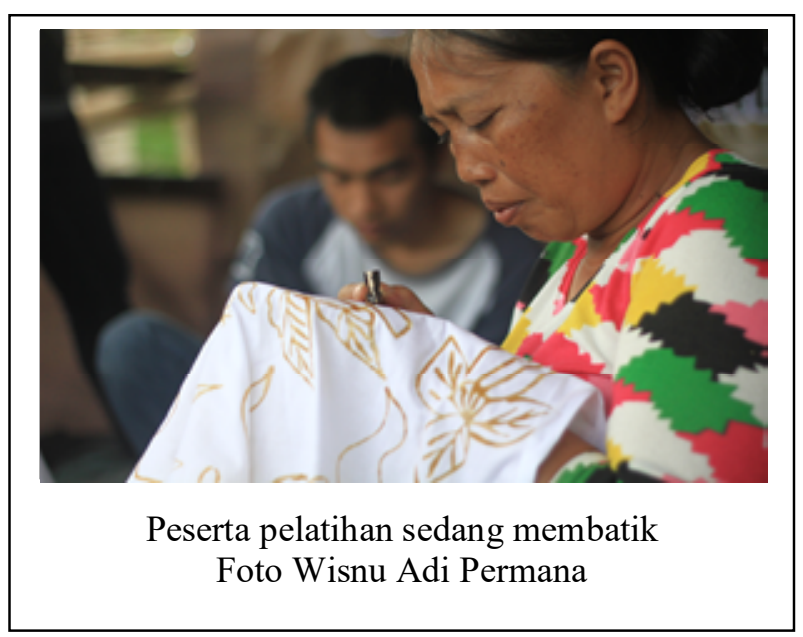

5). Medel yaitu mewarna biru, diperlukan:.

\section{Larutan I: Naptol:}

$$
\begin{aligned}
& 4 \text { gramAS /liter } \\
& 8 \text { gram soda kostik, } \\
& \text { 4-8 gram TRO, }
\end{aligned}
$$

air panas secukupnya, untuk melarutkan

\section{Larutan II: Garam Diazo}

\section{8 -12 gram/literBiru BB}

atau Biru B atau campuran keduanya. air dingin dituang sedikit sedikit sambil diaduk sampai homogen 
a) Batikan dibasahi, dengan memasukan kedalam bak/ember berisi air bersih secara merata kemudian ditiriskan.

b) tuang larutan 1 (naptol) kurang lebih $3 / 4$ nya, dalam bak/ember untuk mewarna, tambahkan air bersih hingga kira-kira menjadi 3 liter (kain batik terendam) dicampur sampai rata.

c) lakukan juga untuk larutan ke 2 (garam), selanjutnya.

d) Pertama, batikan dimasukan kedalam larutan naphtol (larutan I) sedikit demi sedikit dari ujung satu ke ujung sambil ditarik ke atas pelan-pelan dengan hati-hati sampai rata, jangan sampai lilin batikan rusak/pecah. Setelah selesai, kain menjadi berwarna kekuningan, kemudian tiriskan.

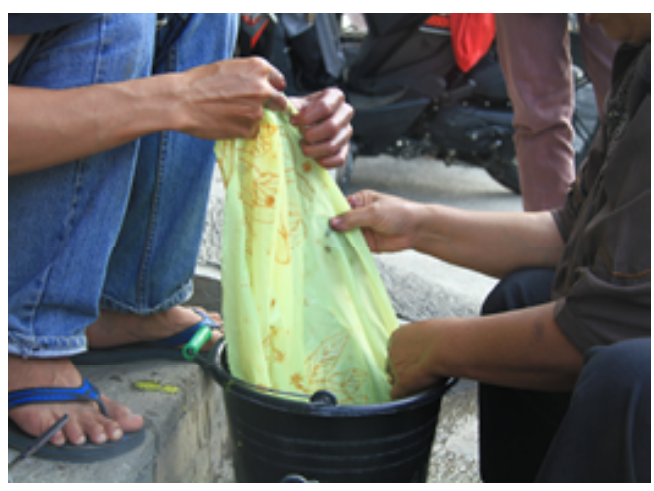

Kain dicelupkan dalan larutan naptol (1) Foto: Wisnu Adi Permana

e) langkah selanjutnya, setelah tiris/atus dimasukan kedalam larutan garam diazo (larutan II) dari ujung masukan sampai ke ujung sampai rata, lakukan dengan hati-hati sama dengan mencelup dalam naptol, kain akan menjadi biru kemudian tiriskan.

f) Dicuci sampai bersih. Apabila kurang tua diulangi dari proses pertama (b) sampai diperoleh warna yang dikehendaki. Sebelumnya sisa warna ditambahkan ke bak celup aduk sampai rata. Setelah kering, kain yang sudah berwarna biru di tutup dengan lilin bagian yang dipertahankan warnanya disebut mbironi. Tujuannya untuk mempertahankan warna yang dikehendaki, agar tidak terkena warna selanjutnya yaitu warna coklat

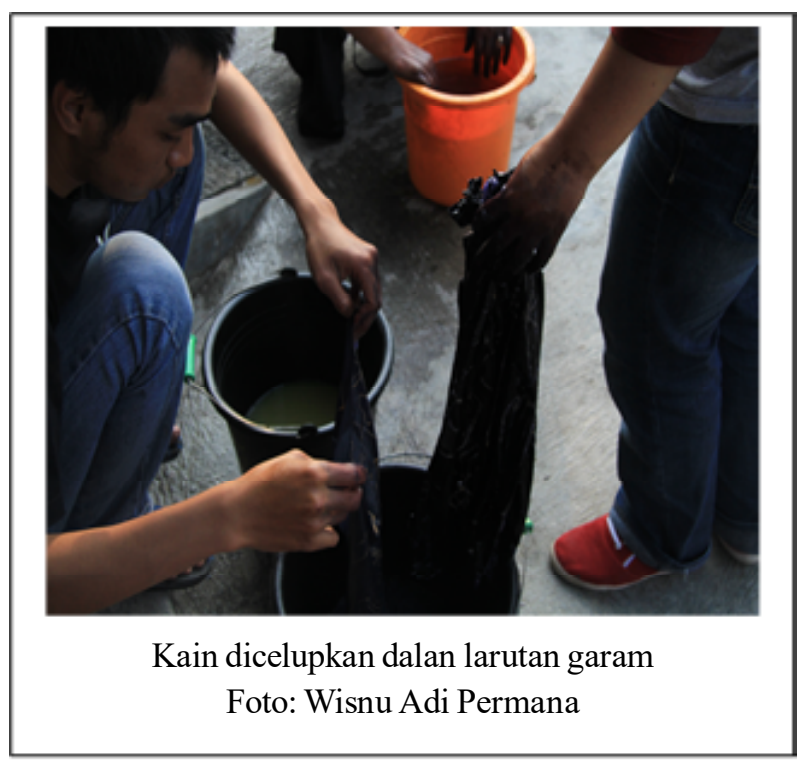

6). Mbironi, ada 3 pekerjaan yaitu: Nglorod/ Ngerok (melepaskan) lilin pada bagian kain batikan yang akan di warna coklat (warna ke 2)., nembok, menutup kain dengan lilin pada bagian kain yang sudah berwarna biru (warna 1) agar tetap berwarna biru dan putih.

7). Nyoga atau mewarna coklat, warna kedua. diperlukan :

Menyiapkan warna coklat/soga, diperlukan Naphtol: 4-5 gram ASLB, 8 gram soda kostik, 4-8 gram TROair panas secukupnya. Garam diazo:8 - 15 gram Merah R atau merah B (warna soga agak kemerahan) atau Kuning GC (soga agak kekuningan), air dingin. Cara melarutkan sama dengan melarutkan untuk warna biru. Selanjutnya siap proses nyoga atau mewarna coklat. Teknik dan proses mewarna coklat sama dengan proses mewarna biru.

8). Nglorod.Nglorod adalah proses menghilangkan lilin pada batikan yang sudah selesai diwarna, dengan cara memasukan batikan kedalam air panas (direbus), sambil diangkat kemudian dimasukan lagi, diulang-ulang hingga lilinnya lepas. Kemudian dicuci dengan air bersih sampai lilinnya hilang. Apabila masih ada lilin yang 


\section{Abdi Seni Jurnal Pengabdian Kepada Masyarakat}

menempel, direbus kembali dan di cuci, diulangulang sampai bersih. Mempercepat terlepasnya lilin, air untuk merebus ditambah tepung tapioka (kanji) atau soda abu, kurang lebih satu sendok makan yang di sudah dilaturkan dengan air terlebih dahulu. Selesai proses mbabar kain dijemur di tempa teduh atau diangin-anginkan.

Pelaksanaan kegiatan pelatihan PPM selesai, sebelum diakhiri diadakan evaluasi hasil pelatihan dan masukan atau umpan balik dari perserta tentang kegiatan pelatihan yang diadakan, dilanjutkan penutupan kegiatan.

\section{KESIMPULAN}

Pengabdian Pada Masyarakat Tematik di desa Campursari sudah dilaksanakan, dengan lancar tidak kurang suatu apa. Pelatihan di fokuskan pada kerajinan batik yang baru di mulai sekitar 3 tahun yang lalu di desa Dalangan.Permasalahan yang dihadapi adalah pada kualitas dan kuantitas.Kualitas produk yang dibuat dengan bahan warna alam kurang rata warnanya, dikarenakan alat dan teknik pewanaan yang belum benar. Alat untuk mewarna yaitu bak celup masih menggunakan ember kecil, namun dengan teknik seperti yang sudah disampaikan dalam pelatihan dapat meminimalisir kekurangan..Waktu yang terbatas, sehingga tidak semua peserta dapat praktek mewarna.Namun demikian secara umum materi pelatihan dengan warna sintetis sudah dapat disampaikan. Mewarna dengan naptol garam dapat mempercepat proses dan meningkatkan produksi.

Saran. Pengembangan pada sektor UMKM Batik Plengkung, perlu menjalin kerja sama dan pendampingan dari instansi terkait maupun akademisi, sehingga permasalahan dari tingkat perajin dapat segera diselesaikan. Batik Plengkung dengan wacana untuk meningkatkan produksi, proses dan bahan warna yang praktis dan murah serta perlu peralatan terutama bak celup yang standart, sehingga proses pewarnaan dapat dilakukan dengan baik,.Meningkatkan kualitas produk batik, warga dusun Dalangan khususnya anggota Batik Plengkung perlu meluangkan waktu secara rutin untuk membatik.Sehingga hasilnya dapat bersaing dengan produk batik dari daerah lainnya.

\section{DAFTAR ACUAN}

\section{Daftar Pustaka}

Balai Besar Penelitihan dan Pengembangan Industri Kerajinan Batik, Katalog batik indonesia Yogyakarta 1997

Departemen perindustrian Badan Penelitian dan Pengembangan Industri, Contoh warnawarna Naphtol, Balai Besar penelitihan dan Pengembangan Industri Kerajinan Batik 1985

Darsono, Estetika, Surakarta, 201

Djelantik, Estetika .Yogyakarta,1999

Gustami, Nukilan Seni Ornamen Inonesia, Yogyakarta, 1980

Grosicki Z, Watson's Textile Design And Colour Elementary Weaves And Figured Fabrics, Boston, 1975

Handoyo, Pengembangan Disain Batik, dalam dinamika Kerajinan dan Batik, Balai Besar Penelitian dan Pengembangan Industri dan Batik, N0. 6 th 1987,ISSN 0216-132-X-)

Sewan Susanto, Seni Kerajinan Batik, Balai Penelitian Batik, Yogyakarta, 1980

J.E Jasper dan Mas Pirngadi, De Batik Kunt s, De Boek \& Kunstrukkerij V/N Mouton \& CO, 1916

Majalah Femina, Simbolisme Dalam Corak dan Warna Batik, NO. 28XIII, 23 Juli 1985.

\section{Daftar Narasumber}

1. Ibu Marsono, 50 tahun, ketua PKK Dusun Sojayan, desa Campursari

2. Ibu Ambar, 35 tahun, ketua kelompok batik plengkung, dusun Dalangan desa Campursari 


\section{Kegiatan Pelatihan Membatik}
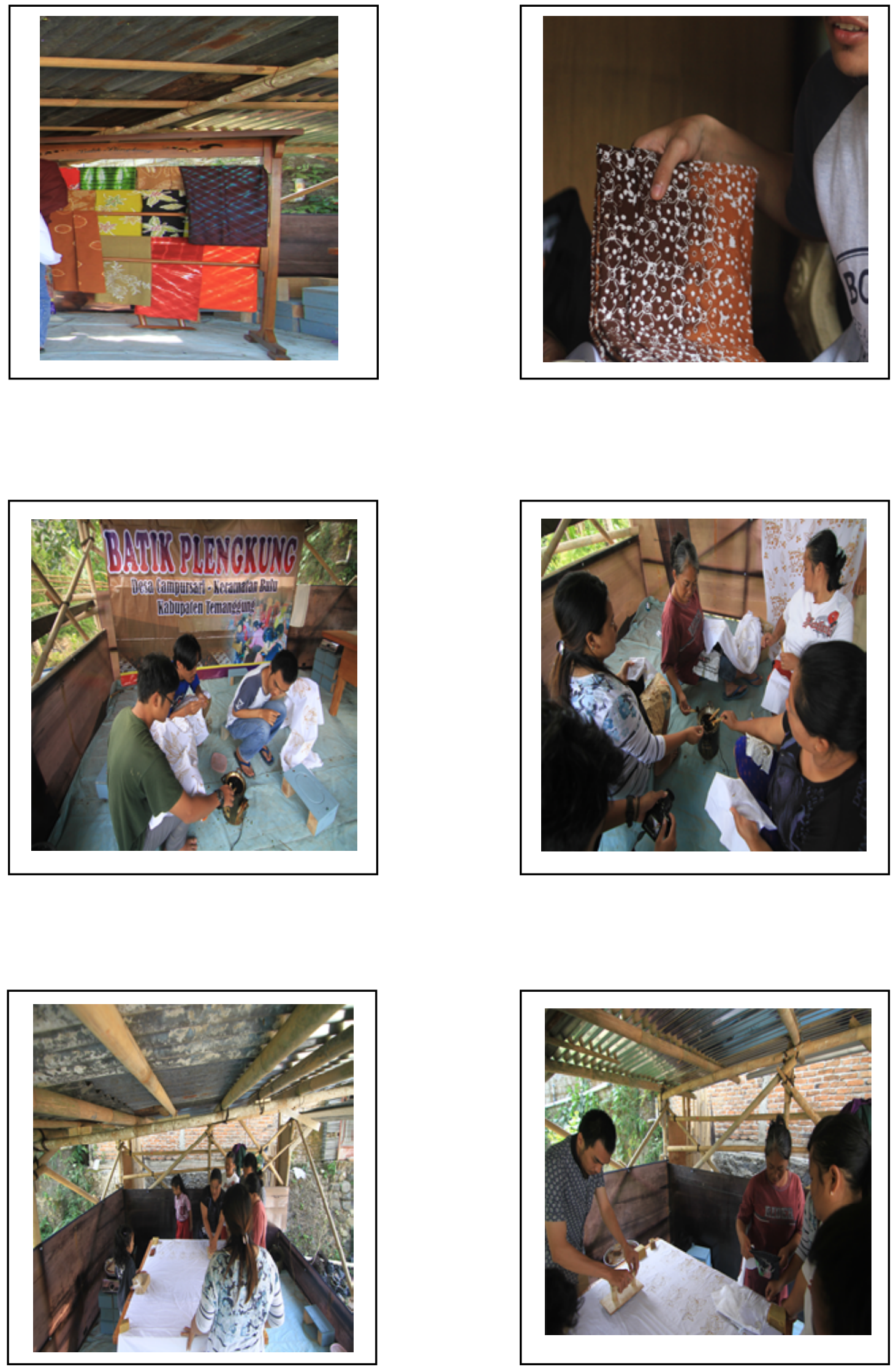

Volume 10 No. 2 Desember 2019 